\title{
Novel species of Huntiella from naturally-occurring forest trees in Greece and South Africa
}

\author{
FeiFei Liu',2, Seonju Marincowitz', ShuaiFei Chen',2, Michael Mbenoun', \\ Panaghiotis Tsopelas ${ }^{3}$, Nikoleta Soulioti ${ }^{3}$, Michael J. Wingfield'
}

I Department of Biochemistry, Genetics and Microbiology (BGM), Forestry and Agricultural Biotechnology Institute (FABI), University of Pretoria, Pretoria 0028, South Africa 2 China Eucalypt Research Centre (CERC), Chinese Academy of Forestry (CAF), ZhanJiang, 524022, GuangDong Province, China 3 Institute of Mediterranean Forest Ecosystems, Terma Alkmanos, 11528 Athens, Greece

Corresponding author: ShuaiFei Chen (shuaifei.chen@gmail.com)

Academic editor: R. Phookamsak | Received 13 April 2020 | Accepted 4 June 2020 | Published 10 July 2020

Citation: Liu FF, Marincowitz S, Chen SF, Mbenoun M, Tsopelas P, Soulioti N, Wingfield MJ (2020) Novel species of Huntiella from naturally-occurring forest trees in Greece and South Africa. MycoKeys 69: 33-52. https://doi. org/10.3897/mycokeys.69.53205

\begin{abstract}
Huntiella species are wood-infecting, filamentous ascomycetes that occur in fresh wounds on a wide variety of tree species. These fungi are mainly known as saprobes although some have been associated with disease symptoms. Six fungal isolates with typical culture characteristics of Huntiella spp. were collected from wounds on native forest trees in Greece and South Africa. The aim of this study was to identify these isolates, using morphological characters and multigene phylogenies of the rRNA internal transcribed spacer (ITS) region, portions of the $\beta$-tubulin (BT1) and translation elongation factor $1 \alpha$ (TEF-1 $\alpha$ ) genes. The mating strategies of these fungi were also determined through PCR amplification of mating type genes. The study revealed two new species; one from Platanus orientalis in Greece and one from Colophospermum mopane and Senegalia nigrescens in South Africa. These novel taxa have been provided with the names, $H$. hellenica sp. nov. and $H$. krugeri sp. nov., respectively. The former species was found to have a homothallic and the latter a heterothallic mating system.
\end{abstract}

\section{Keywords}

Ceratocystidaceae, Ceratocystis moniliformis Complex, Colophospermum mopane, Huntiella, Platanus orientalis, saprobes, Senegalia nigrescens 


\section{Introduction}

Huntiella species are members of the family Ceratocystidaceae (Microascales, Sordariomycetes) as defined by De Beer et al. (2014). This family includes 15 genera, namely Ambrosiella, Berkeleyomyces, Bretziella, Catunica, Ceratocystis, Chalaropsis, Davidsoniella, Endoconidiophora, Huntiella, Meredithiella, Phialophoropsis, Solaloca, Tielaviopsis, Toshiolenlla and Wolfgangiella (De Beer et al. 2014, 2017; Mayers et al. 2015, 2020; Nel et al. 2018). The type species of Huntiella, H. moniliformis, was first isolated from a sweetgum (Liquidambar styracifua) in Texas, USA (Von Schrenk 1903). It was initially described as Ceratostomella moniliformis (Hedgcock 1906) and later transferred to Ceratocystis (Moreau 1952). When the family Ceratocystidaceae was redefined (De Beer et al. 2014), Huntiella was established as a distinct genus, which can be distinguished from Ceratocystis and other members of the Ceratocystidaceae, based on their unique morphological features (Davidson 1935; Van Wyk et al. 2006; Wingfield et al. 2013). Most Huntiella spp. are easily recognised by a relatively-thick collar plate connecting the ascomatal necks and bases and ascomatal bases that are rough and ornamented with conical spines (Hedgcock 1906). In addition, aleurioconidia are rarely found in Huntiella species unlike most species of Ceratocystis sensu stricto with which they were previously confused (Hedgcock 1906; De Beer et al. 2014; Mbenoun et al. 2016).

Many species in the Ceratocystidaceae are important pathogens of woody plants, including agricultural, fruit and forest tree crops (Kile 1993; Roux and Wingfield 2009). These pathogens result in a multiplicity of symptoms, such as branch and stem cankers, vascular staining, wilt, root rot, die-back and fruit rot (Kile 1993; Harrington 2004; Roux and Wingfield 2009). Huntiella spp. are generally considered saprobes or weak pathogens associated with relatively-minor lesions or sap stain of timber (Van Wyk et al. 2004, 2006, 2011; Tarigan et al. 2010; Kamgan Nkuekam et al. 2012; Chen et al. 2013; Mbenoun et al. 2016; Liu et al. 2018). However, there have been a few reports of more severe disease symptoms and even mortality caused by Huntiella spp. (Cristobal and Hansen 1962; De Errasti et al. 2015)

Huntiella species are most commonly isolated from freshly-made wounds on trees, to which they are vectored by insects, especially sap-feeding beetles in the Nitidulidae (Heath et al. 2009; Kamgan Nkuekam et al. 2012; Mbenoun et al. 2016, 2017). It has been suggested that the relationship between Huntiella species and sap beetle is symbiotic and mutually beneficial, as the insects benefit from essential nutritional supplementation from their fungal partners, while the fungi benefit from transportation and access to scanty and ephemeral substrates (Mbenoun et al. unpublished data). Moreover, one species (H. bhutanensis) is found in association with the bark beetle Ips schmutzenhoferi (Van Wyk et al. 2004), which is similar to various important species of Endoconidiophora (De Beer et al. 2014), although the nature of insect-fungus interaction in this association is unknown.

Huntiella spp. are particularly interesting in terms of their mating biology. Huntiella fecunda and $H$. moniliformis were, for example, shown to exhibit a unisexual mating system, unlike the many heterothallic species found in this genus (Wilson et al. 2015; Liu et al. 2018). More recent studies have revealed a diversity of mating systems 
in Huntiella spp., including those that are homothallic, heterothallic and unisexual (Wilson et al. 2015; Liu et al. 2018). Efforts are consequently being made to collect these fungi, providing a basis for future fungal genetics studies, but also, together with genomics data (Wingfield et al. 2016), to better understand their biology.

Huntiella species are most commonly found in tropical and sub-tropical regions of the world (Van Wyk et al. 2004, 2006, 2011; Kamgan Nkuekam et al. 2012; De Errasti et al. 2015; Mbenoun et al. 2014, 2016; Liu et al. 2018). Twenty-nine species are currently recognised in the genus (Liu et al. 2018). These fungi are grouped in three well-supported genealogical lineages that correspond to geographic centres, where they appear to have radiated (Mbenoun et al. 2016; Liu et al. 2018). These include species in an African Clade known only from Africa, an Asian Clade distributed across Asia and an Indo-Pacific Clade found in Australia and Pacific Islands and some parts of Asia. However, the diversity of Huntiella in most regions, including especially Europe, North and South America, is largely unexplored.

The objective of this study was to identify two fungal isolates collected from Platanus orientalis L. in Greece and four isolates from Colophospermum mopane (Benth.) J. Léonard and Senegalia nigrescens (Oliv.) P. Hurter in South Africa. These fungi displayed typical culture characteristics of Huntiella spp., including rapid growth on agar medium, white fluffy mycelia when young, as well as the production of fruity aroma. Identification was accomplished, based on morphology and multigene phylogenies for the ITS, BT1 and TEF- $1 \alpha$ gene regions. Furthermore, we considered the mating biology of these isolates in order to complement our taxonomic studies.

\section{Materials and methods}

\section{Fungal isolations}

Three South African Huntiella isolates were collected from fresh wounds of Colophospermum mopane in Kruger National Park in April 2009 and another one of the South African isolates was obtained from a broken branch of a Senegalia nigrescens tree damaged by elephants in Kruger National Park in June 2010. The isolates from Greece were obtained from the stump of a Platanus orientalis tree that was cut about two months before sampling, in a natural forest along the banks of the Spercheios River in Phthiotis Regional Unit during November 2018. Isolation from wood samples was performed using a trapping technique originally described by Grosclaude et al. (1988). This is a standard diagnostic protocol for the isolation of Ceratocystis platani (Walter) Engelbrecht \& Harrington using freshly-cut twigs of P. orientalis as bait (OEPP/EPPO 2014).

Isolates from Greece were made by transferring ascospore masses from the tips of the ascomata on the surface of Platanus twig baits, formed on infected wood surface, to 2\% malt extract agar (MEA: $20 \mathrm{~g}$ Biolab malt extract, $20 \mathrm{~g}$ Difco agar, 1 litre water), using a sterile needle under a dissection microscope (Carl Zeiss Co. Ltd., Oberkochen, Germany). The South African isolate was obtained by transferring mycelial strands from infected wood on to MEA. Primary isolations were incubated 
for 3-7 d at $25^{\circ} \mathrm{C}$. From these isolations, purified cultures from single hyphal tips were prepared for morphological characterisation, phylogenetic analyses and matingtype studies. All purified isolates were deposited in the culture collection (CMW) of the Forestry and Agricultural Biotechnology Institute (FABI), University of Pretoria, South Africa and the living culture collection (PPRI) of the South African National Collection of Fungi (NCF), Roodeplaat, Pretoria, South Africa. The dried-down type specimens were deposited in the National Collection of Fungi (PREM), Roodeplaat, Pretoria, South Africa.

\section{DNA extraction, PCR and sequencing}

All the isolates obtained in this study were used for DNA sequence-based characterisation. Total genomic DNA was extracted from the mycelium of isolates grown on $2 \%$ MEA for $3-4 \mathrm{~d}$ at $25^{\circ} \mathrm{C}$, using Prepman Ultra Sample Preparation Reagent (Thermo Fisher Scientific, Waltham, MA, USA) following the manufacturer's protocols. Three gene regions were amplified for sequencing and phylogenetic analyses. These included the Internal Transcribed Spacer (ITS) regions 1 and 2, including the 5.8S rRNA, a partial $\beta$-tubulin 1 gene (BT1) and a partial Translation Elongation factor- $1 \alpha$ gene (TEF-1 $\alpha$ ), amplified using the set of primers as described by Liu et al. (2018).

A total volume of $25 \mu \mathrm{l}$ PCR reaction mixture contained $1 \mu \mathrm{l}$ of DNA template, $0.5 \mu \mathrm{l}(10 \mathrm{pM})$ of each primer (Forward and Reverse), $5 \mu \mathrm{l}$ MyTaq PCR buffer (Bioline $\mathrm{GmbH}$, Germany) and $0.3 \mu \mathrm{l}$ of MyTaq DNA Polymerase (Bioline GmbH, Germany). The PCR reactions were conducted using an Applied Biosystems ProFlex PCR System (Thermo Fisher Scientific, Waltham, MA, USA). The PCR programme for amplification of the ITS, BT1 and TEF1- $\alpha$ gene regions was as follows: an initial denaturation step at $95^{\circ} \mathrm{C}$ for $5 \mathrm{~min}$ followed by 35 cycles of $30 \mathrm{~s}$ at $95^{\circ} \mathrm{C}, 45 \mathrm{~s}$ at $56^{\circ} \mathrm{C}$ and $60 \mathrm{~s}$ at $72^{\circ} \mathrm{C}$ and a final extension step at $72^{\circ} \mathrm{C}$ for $10 \mathrm{~min}$. Amplified fragments were purified using ExoSAP-IT ${ }^{\mathrm{TM}}$ PCR Product Cleanup Reagent (Thermo Fisher Scientific, Waltham, MA, USA) to remove excess primers and dNTPs. Amplicons were sequenced in both directions using an ABI PRISM ${ }^{\mathrm{TM}} 3100$ DNA sequencer (Applied Biosystems, USA) at the Sequencing Facility of the Faculty of Natural and Agricultural Sciences, University of Pretoria, Pretoria, South Africa.

\section{Multi-gene phylogenetic analyses}

The programme Geneious v. 7.0 was used to edit and assemble raw sequence reads into contigs (Kearse et al. 2012). Sequence data for representative type isolates of all described Huntiella spp. (except H. decorticans) were downloaded from GenBank (http:// www.ncbi.nlm.nih.gov). The sequences were aligned using MAFFT v. 7 with an online FFT-NS-i strategy (https://mafft.cbrc.jp/alignment/server/; Katoh and Standley 2013) 
and confirmed visually. Sequences for the novel species discovered in this study were deposited in GenBank.

Single gene sequence datasets of the ITS, BT1 and TEF- $1 \alpha$ and the combined dataset of the three gene regions were analysed using Maximum Likelihood (ML), Maximum Parsimony (MP) and Bayesian Inference (BI). The appropriate substitution model for each dataset was obtained using the software package jModeltest v. 2.1.5 (Posada 2008). The ML phylogenetic analyses were conducted using PhyML v. 3.0 (Guindon and Gascuel 2003). Confidence levels for the nodes were determined using 1000 bootstrap replicates. MP analyses were performed using PAUP v. 4.0b10 (Swofford 2003). Gaps were treated as a fifth character. BI analyses were conducted using MrBayes v. 3.2.6 (Ronquist et al. 2012) on the CIPRES Science Gateway v. 3.3. Four Markov Chain Monte Carlo (MCMC) chains were run from a random starting tree for five million generations and trees were sampled every 100 generations. Twenty-five percent of the trees sampled were discarded as burn-in and the remaining trees were used to construct $50 \%$ majority rule consensus trees. Ceratocystis cercfabiensis (isolate CMW 43029) was used as the outgroup taxon for all the phylogenetic analyses. The resulting trees were visualised using MEGA v. 7.

\section{Microscopy, growth study and mating-type assignment}

Morphological features were studied on the isolates grown on 2\% MEA. The fruiting structures were initially mounted in water and this was later replaced with $85 \%$ lactic acid and in which measurements were made and images captured. Nikon microscopes (Eclipse Ni, SMZ 18, Nikon, Tokyo, Japan) mounted with a camera (Nikon DS Ri-2) were used for all observations. Fifty measurements of each relevant microscopic structure were made when available and these are presented as minimum-maximum and average \pm standard deviation.

A study of growth in culture was conducted at temperatures from $5-35^{\circ} \mathrm{C}$ at $5{ }^{\circ} \mathrm{C}$ intervals on the $90 \mathrm{~mm}$ Petri dishes containing 2\% MEA. A mycelial plug $(5 \mathrm{~mm}$ diam.) taken from an actively-growing colony was placed at the centres of Petri dishes. Four replicates per isolate were used to study growth rate and the experiment was repeated once. Colony diameters were assessed by taking two measurements perpendicular to each other for all isolates daily and growth rates were calculated. Colony characteristics were described on the same medium used for the growth studies and colours were assessed using the colour charts of Rayner (1970).

The mating type (MAT) of the studied Huntiella spp. was determined, based on the results of the mating type PCR reactions (Wilson et al. 2015). Primers, to see which of the MAT genes, Oman_111_F and Oman_111_R were thus used to amplify a 335 bp fragment of the MAT1-1-1 gene and Om_Mo_121_F and Om_ Mo_121_R to amplify a 572 bp fragment of the MAT1-2-1 gene, as described by Wilson et al. (2015). 


\section{Results}

\section{Fungal isolations}

Six isolates resembling Huntiella spp. were included in this study. Two isolates had ascomata with long necks, conical spines on the ascomatal bases and hat-shaped ascospores and four isolates had only thielaviopsis-like asexual state (Van Wyk et al. 1991). Four isolates were collected from Colophospermum mopane and Senegalia nigrescens in the Kruger National Park of South Africa and two isolates were from Platanus orientalis in Greece. Ascomata resembling Huntiella spp. were observed on twig baits from P. orientalis samples from Greece and two isolates were obtained in pure culture. All isolates obtained in this study have been preserved in the culture collections described above (Table 1).

\section{Multi-gene phylogenetic analyses}

All six isolates, included in this study, were successfully sequenced at all three selected gene regions for phylogenetic analyses, resulting in DNA sequence data of approximately 614,574 and $830 \mathrm{bp}$ for the ITS, BT 1 and TEF- $1 \alpha$ gene regions, respectively. These newly-generated sequences were deposited in GenBank (Table 1). Comparisons with reference sequences of previously-described Huntiella spp. produced a concatenated sequence alignment which was deposited in TreeBASE (no. 26341).

The three tree topologies resulting from ML, MP and BI were concordant and showed similar phylogenetic relationships amongst taxa (Fig. 1, Suppl. materials 1-3: Figs S1-S3). Based on the phylogenetic analyses of the BT1 (Suppl. materil 2, Fig. S2), TEF-1 $\alpha$ (Suppl. material 3: Fig. S3) and the combined gene regions (Fig. 1), the six isolates clustered in two well-supported clades, clearly separated from each other and from previously described Huntiella spp. The ITS tree (Suppl. material 1: Fig. S1) provided a poor resolution to separate the species. All the isolates grouped in the African Clade of Huntiella spp. (Fig. 1).

\section{Taxonomy}

Huntiella hellenica F.F. Liu. Marinc. \& M.J. Wingf., sp. nov. MycoBank No: 835637

Fig. 2

Etymology. The name refers to the country, Greece where this fungus was collected.

Mating strategy. Homothallic, with sexually complementary isolates having both the MAT1-1-1 and MAT1-2-1 genes.

Sexual state. Ascomata produced in 2\% MEA in a week, perithecial; ascomatal bases mostly embedded in thick or loose mycelial mat, globose to ellipsoidal or obpyriform, pale brown when young, becoming dark brown with age, 173-377 $\mu \mathrm{m}$ long (avg. $238.8 \mu \mathrm{m}$ ), 


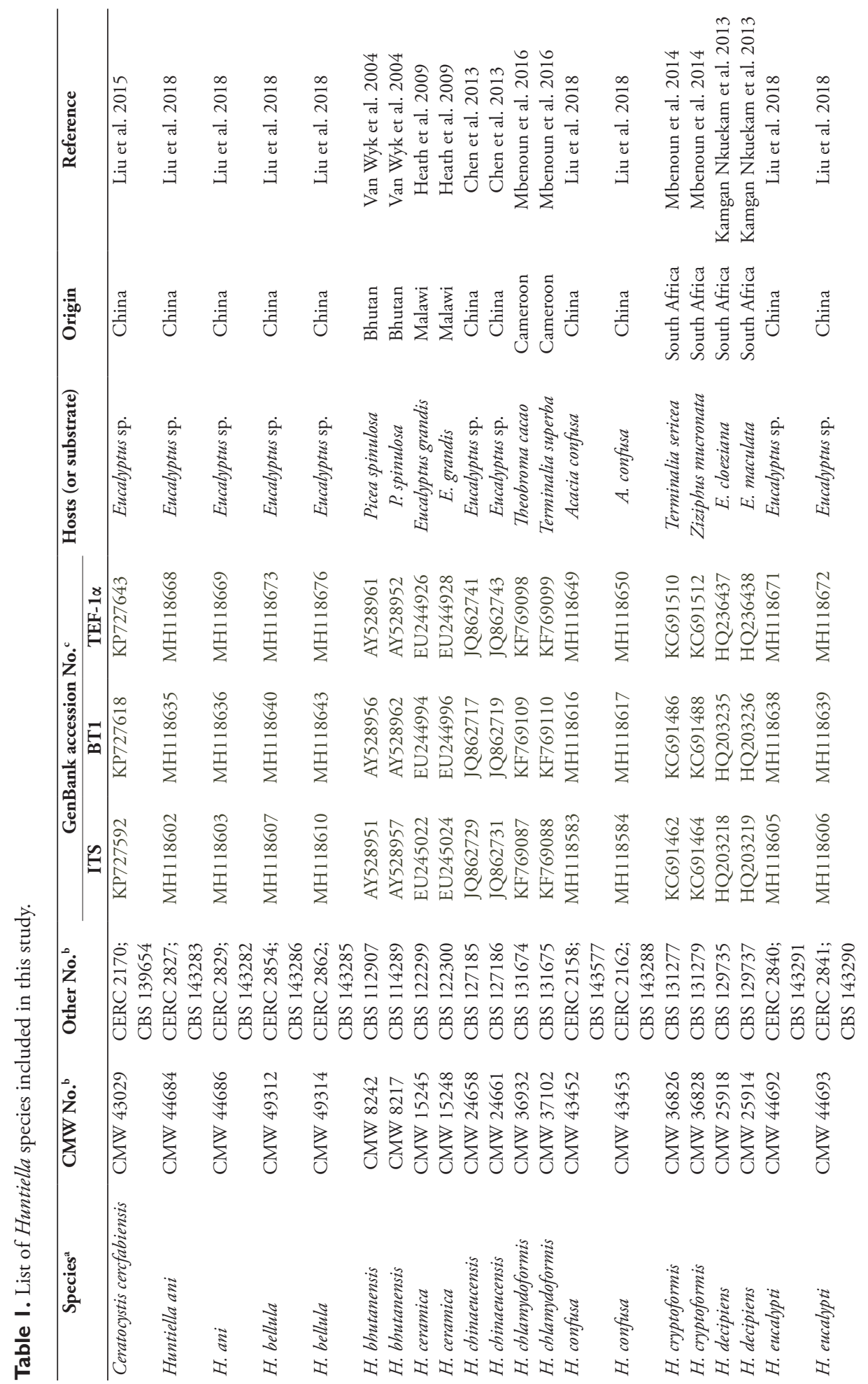




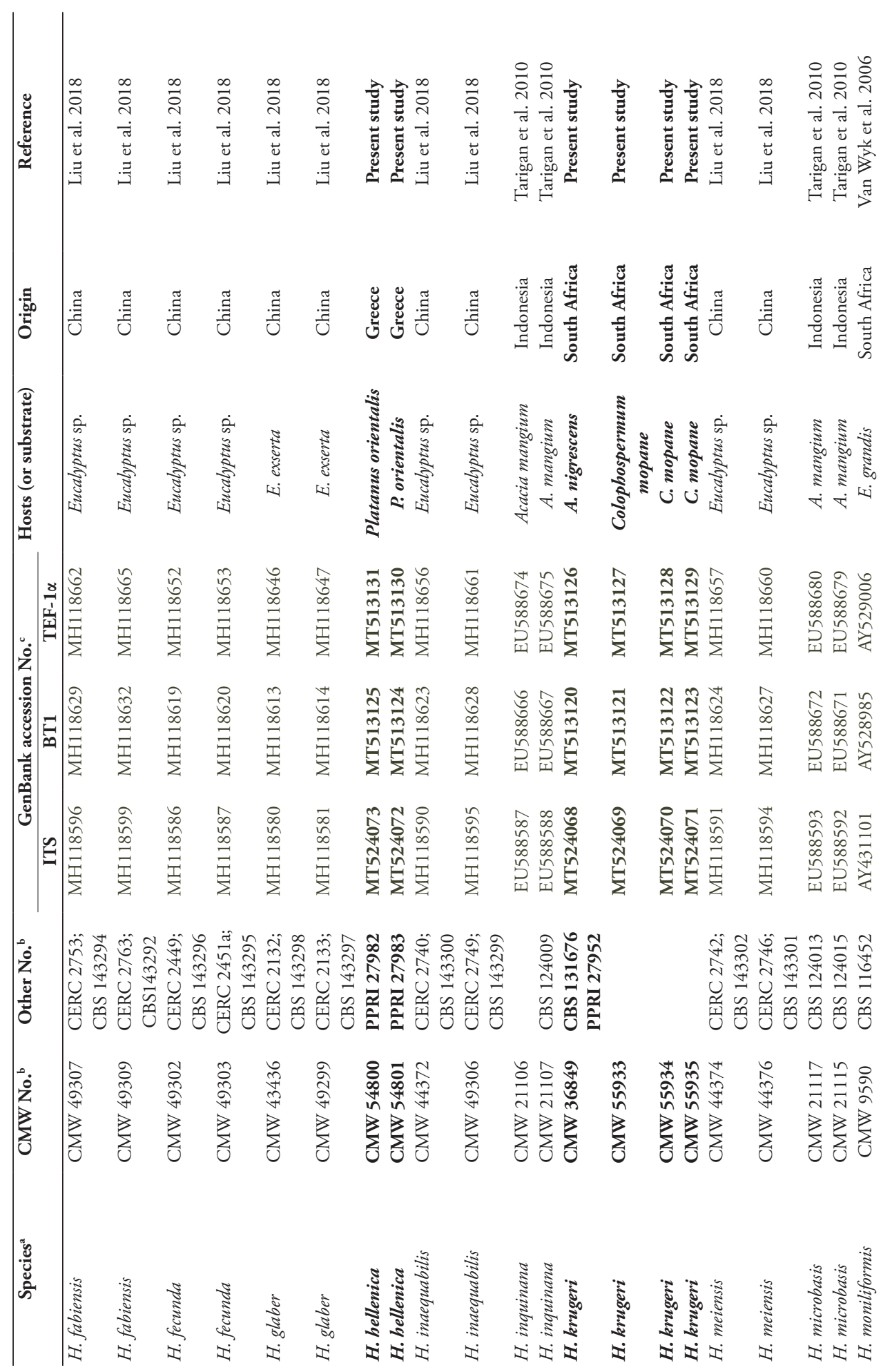




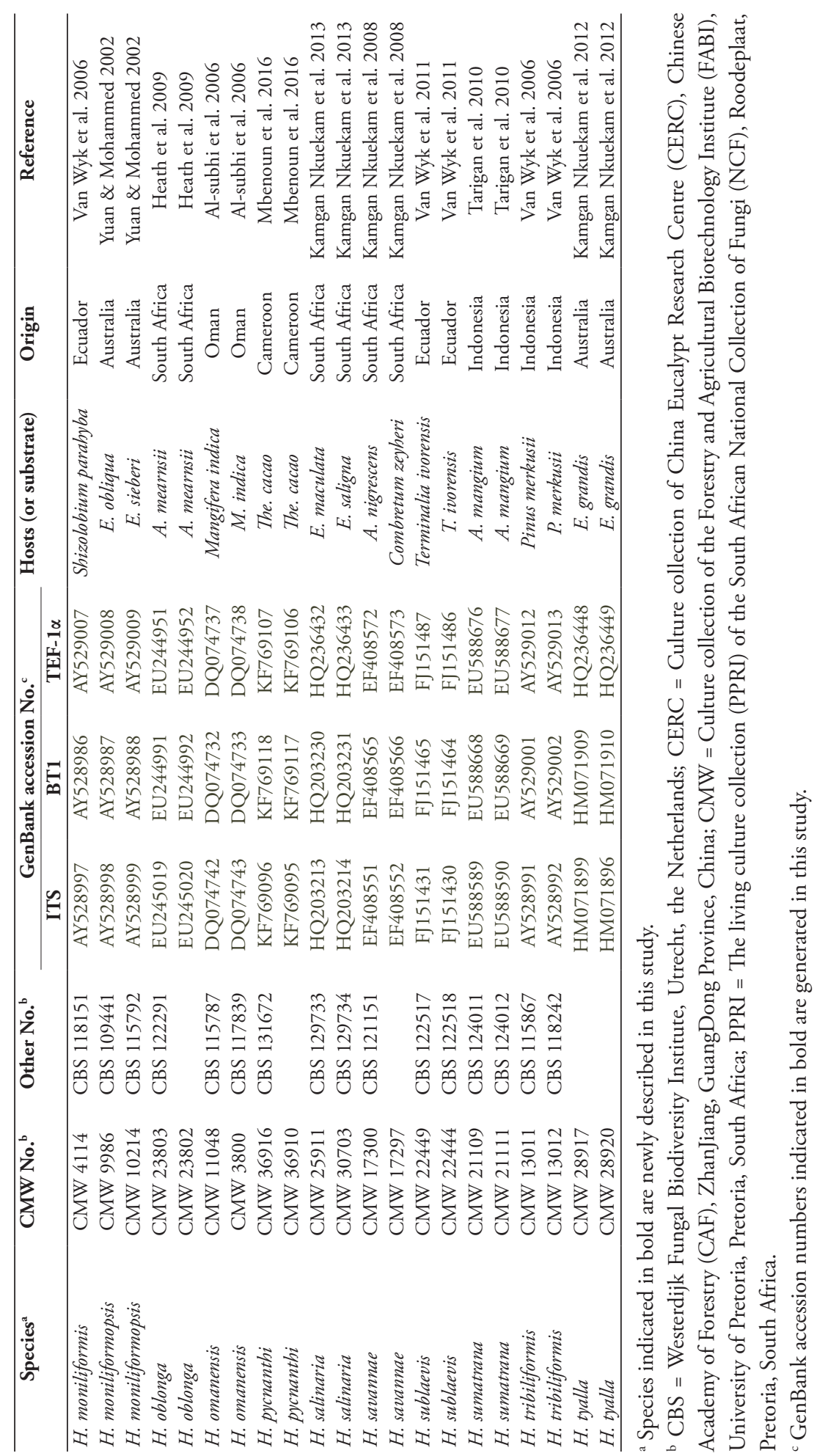




\section{ITS+BT1+TEF}

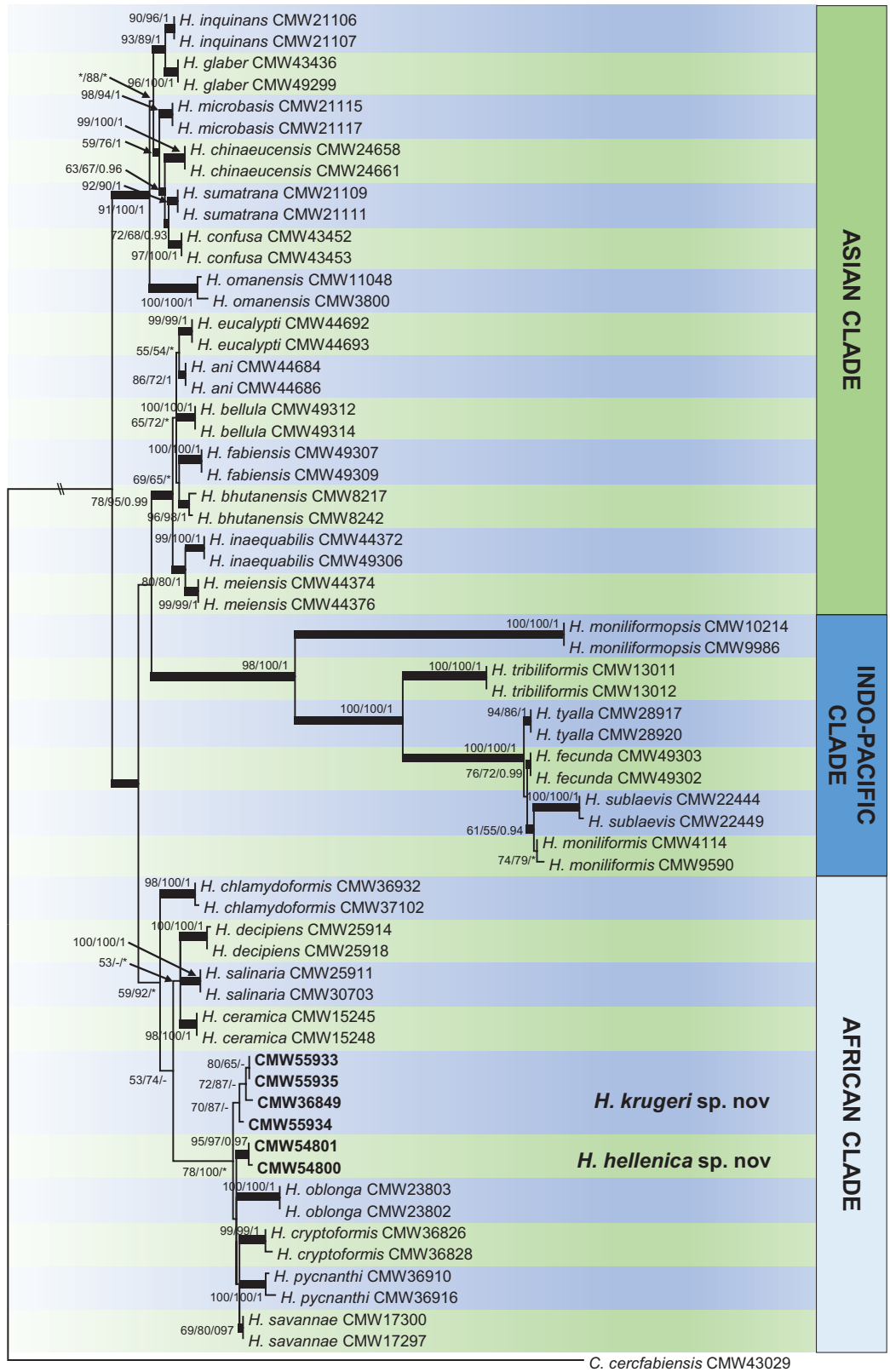

Figure I. ML tree of Huntiella species generated from the combined DNA sequence data of ITS, BT1 and TEF- $1 \alpha$ DNA. Sequences generated from this study are printed in bold type. Bold branches indicate posterior probabilities values $\geq 0.9$. Bootstrap values and posterior probabilities values are presented above branches as ML/MP/BI. Bootstrap value $<50 \%$ or probabilities values $<0.9$ are marked with *. Nodes lacking the support value are marked with -. Ceratocystis cercfabiensis (CMW 43029) represents the outgroup. 
157-493 $\mu \mathrm{m}$ wide (avg. $218.2 \mu \mathrm{m}$ ), ornamented with spine-like structures, dark brown, conical, 12-29 $\mu \mathrm{m}$ long, 4-9 $\mu \mathrm{m}$ wide at base becoming attenuated; ostiolar necks upright, straight, occasionally situated at off-centre of base, darker than base when young, 344$616 \mu \mathrm{m}$ long (avg. $515.5 \mu \mathrm{m}$ ), 34-60 $\mu \mathrm{m}$ wide (avg. $46.6 \mu \mathrm{m}$ ) at base, gradually tapering towards apex; ostiolar hyphae hyaline, straight to divergent, 15-39 $\mu \mathrm{m}$ long, 1-3 $\mu \mathrm{m}$ wide, tapering towards apex. Asci evanescent. Ascospores hyaline, subglobose, aseptate, covered with sheath giving a hat-like feature in side view, $4-5.5 \times 3-4.5 \mu \mathrm{m}(5 \pm 0.23 \times 4 \pm$ $0.28 \mu \mathrm{m})$ excluding sheath.

Asexual state. Thielaviopsis-like Conidiophores macronematous, simple or branched; when branched radiating from basal cell once, often reduced to conidiogenous cells. Conidiogenus cells endoblastic, hyaline, varying from lageniform to cylindrical depending spore shape; in case of thick barrel-shaped conidia, apex often becoming wider than base. Conidia hyaline, 1-celled, in two recognisable shapes; majority ellipsoidal to barrel-shaped (side swollen, ends round), typical fat barrel-shaped $5-8 \times 4.5-7.5 \mu \mathrm{m}(5.9 \pm 0.61 \times 5.3 \pm 0.55 \mu \mathrm{m})$, width of some barrel-shaped ranging $2.5-4 \mu \mathrm{m}$ wide; rectangular-shaped (side straight, ends truncated), not commonly found, $5-9 \times 1-3 \mu \mathrm{m}(6.9 \pm 1.18 \times 2.3 \pm 0.38 \mu \mathrm{m})$. Aleurioconidia not observed.

Culture characteristics. Cultures on 2\% MEA in dark in $8 \mathrm{~d}$ showing circular growth with even edge, mycelium flat, superficial, medium dense and texture becoming pelt-like with age, colour above not uniform, salmon (11f') to ochreous (15b') with inner half irregularly umber $(13 \mathrm{~m})$, below ochreous (15b') with inner half irregularly umber (13i') at centre. Optimum growth temperatures at $30^{\circ} \mathrm{C}$ at $9.6 \mathrm{~mm} / \mathrm{d}$, followed by at $25^{\circ} \mathrm{C}(7.6 \mathrm{~mm} / \mathrm{d}), 35^{\circ} \mathrm{C}(7.2 \mathrm{~mm} / \mathrm{d}), 20{ }^{\circ} \mathrm{C}(4.7 \mathrm{~mm} / \mathrm{d}), 15^{\circ} \mathrm{C}(3.2 \mathrm{~mm} / \mathrm{d})$, $10{ }^{\circ} \mathrm{C}(1.1 \mathrm{~mm} / \mathrm{d})$ and $5^{\circ} \mathrm{C}(0.2 \mathrm{~mm} / \mathrm{d})$.

Specimens examined. Greece, Phthiotis, near the village Kastri, occurring on freshly-cut stumps of Platanus orientalis in a natural forest along the banks of the Spercheios River, Nov. 2018, P. Tsopelas \& N. Soulioti, PREM 62889, holotype (dried culture of CMW 54800), culture ex-holotype CMW 54800 = PPRI 27982, other cultures CMW 54801 = PPRI 27983.

Notes. The sexual state of $H$. hellenica developed at temperatures over $25^{\circ} \mathrm{C}$. Cultures incubated at $20^{\circ} \mathrm{C}$ and below produced only the asexual state. Huntiella hellenica is closely related to $H$. savannae (Kamgan Nkuekam et al. 2008), H. pycnanthi (Mbenoun et al. 2016) and H. krugeri. It can, however, be distinguished from these two species by the dimensions of ascomatal necks and barrel-shaped conidia and growth rate. Huntiella hellenica produced shorter (average $515.5 \mu \mathrm{m}$ long) ascomatal necks than $H$. savannae (average $579 \mu \mathrm{m}$ long) and $H$. pycnanthi (average $673 \mu \mathrm{m}$ long). Huntiella hellenica had larger (average $6.9 \times 2.3 \mu \mathrm{m}$ ) barrelshaped conidia than $H$. savannae (average $4.8 \times 3 \mu \mathrm{m}$ ) and $H$. pycnanthi (average 6 $\times 3 \mu \mathrm{m})$. Optimal temperature for growth of $H$. hellenica was $30^{\circ} \mathrm{C}$, similar to $H$. savannae and $H$. pycnanthi, but $H$. hellenica differed from $H$. pycnanthi in growing minimally at $10{ }^{\circ} \mathrm{C}$ and below. 

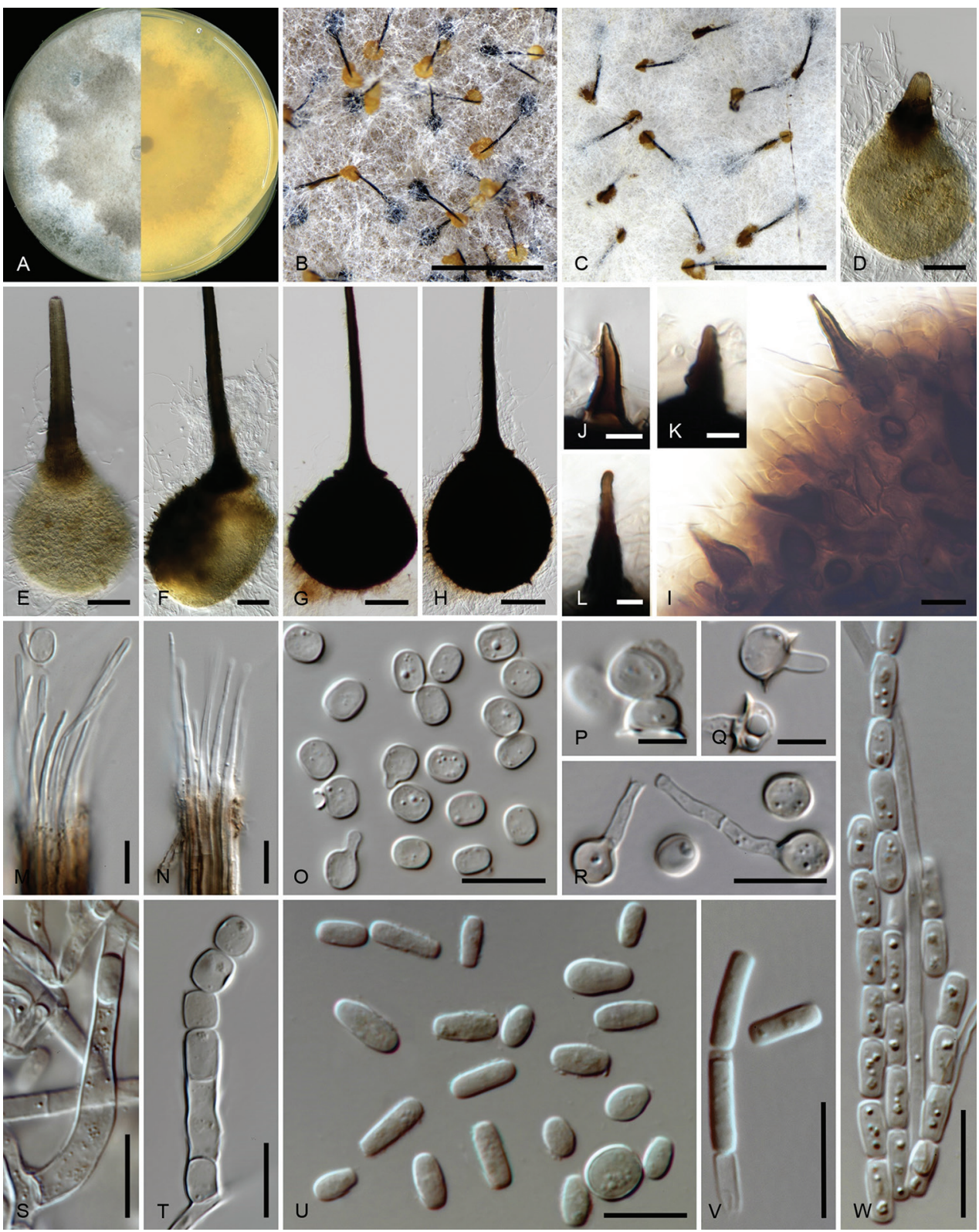

Figure 2. Micrographs of Huntiella hellenica sp. nov. (ex-holotype CMW $54800=$ PPRI 27982) A culture grown on $2 \% \mathrm{MEA}$ at $30^{\circ} \mathrm{C}$ (optimum growth temperature) in the dark for $34 \mathrm{~d} \mathbf{B}, \mathbf{C}$ colony with ascomatal base embedded in mycelia with ascospore mass at the tip of ostiolar neck $\mathbf{D}-\mathbf{F}$ young ascoma showing development of ostiolar neck and less-pigmented base $\mathbf{G}, \mathbf{H}$ mature ascoma ornamented with spines I close-up of ascomatal wall showing spines $\mathbf{J}-\mathbf{L}$ close up of ornament (spin-like) $\mathbf{M}, \mathbf{N}$ Ostiolar hyphae $\mathbf{O}$ Ascospores $\mathbf{P}$ Ascospores covered with sheath appearing like a hat $\mathbf{Q}, \mathbf{R}$ Germinating ascospores $\mathbf{S}$ Lageniform conidiogenous cell $\mathbf{T}$ Cylindrical-shape conidiogenous cell $\mathbf{U}$ Conidia in various shapes from diverse barrel-shaped to rectangular-shaped $\mathbf{V}$ rectangular-shaped conidia $\mathbf{W}$ chains of conidia. Scale bars: $1 \mathrm{~mm}(\mathbf{B}, \mathbf{C}) ; 50 \mu \mathrm{m}(\mathbf{D}-\mathbf{H}) ; 10 \mu \mathrm{m}(\mathbf{I}-\mathbf{W})$. 
Huntiella krugeri F.F. Liu. Marinc. \& M.J. Wingf., sp. nov. MycoBank No: 835638

Fig. 3

Etymology. The name refers to the Kruger National Park in South Africa, where this fungus was collected.

Mating strategy. Heterothallic with isolates having either a MAT1-1-1 gene or a MAT1-2-1 gene.

Sexual state. Not observed.

Asexual state. Produced on 2\% MEA in 3 weeks. Thielaviopsis-like. Conidiophores macronematous, upright, simple or branched in one tier, 29-37 $\mu \mathrm{m}$ in length, often reduced to conidiogenous cells; Conidiogenous cells enteroblastic, lageniform, 10-20 $\mu \mathrm{m}$ long, 1.5-3 $\mu \mathrm{m}$ wide, tapering towards apex. Conidia hyaline, rectangularshaped, usually straight, with top-end conidium often club-shaped, 4-11 $\times 1-2 \mu \mathrm{m}$ (avg. $6.2 \times 1.7 \mu \mathrm{m})$. Aleurioconidia hyaline, holoblastic, mostly terminal, ellipsoidal to subglobose with an extended tube-like base, club-shaped, 4-7 × 2-3 $\mu \mathrm{m}(5.6 \pm$ $0.76 \times 2.5 \pm 0.24 \mu \mathrm{m})$.

Culture characteristics. Cultures on 2\% MEA in dark in $8 \mathrm{~d}$ showing circular growth with even edge, mycelium superficial, flat, dense, colour above uniformly white, below luteous (19). Optimum growth temperatures were at $30^{\circ} \mathrm{C}$ at $9 \mathrm{~mm} / \mathrm{d}$, followed by at $25^{\circ} \mathrm{C}(8.2 \mathrm{~mm} / \mathrm{d}), 35^{\circ} \mathrm{C}(6.2 \mathrm{~mm} / \mathrm{d}), 20^{\circ} \mathrm{C}(6 \mathrm{~mm} / \mathrm{d}), 15^{\circ} \mathrm{C}(3.4 \mathrm{~mm} / \mathrm{d}), 10{ }^{\circ} \mathrm{C}$ $(0.9 \mathrm{~mm} / \mathrm{d})$ and $5^{\circ} \mathrm{C}(0.3 \mathrm{~mm} / \mathrm{d})$.

Specimens examined. South Africa, Mpumalanga, Kruger National Park, Satara rest camp, Senegalia nigrescens, June 2010, M. Mbenoun, PREM 62883, holotype (dried culture of CMW 36849), culture ex-holotype CMW 36849 = CBS $131676=$ PPRI 27952.

Other cultures. South Africa, Mpumalanga, Kruger National Park, Punda Maria, Colophospermum mopane, April 2009, M. Mbenoun, CMW 55933, CMW 55934, CMW 55935.
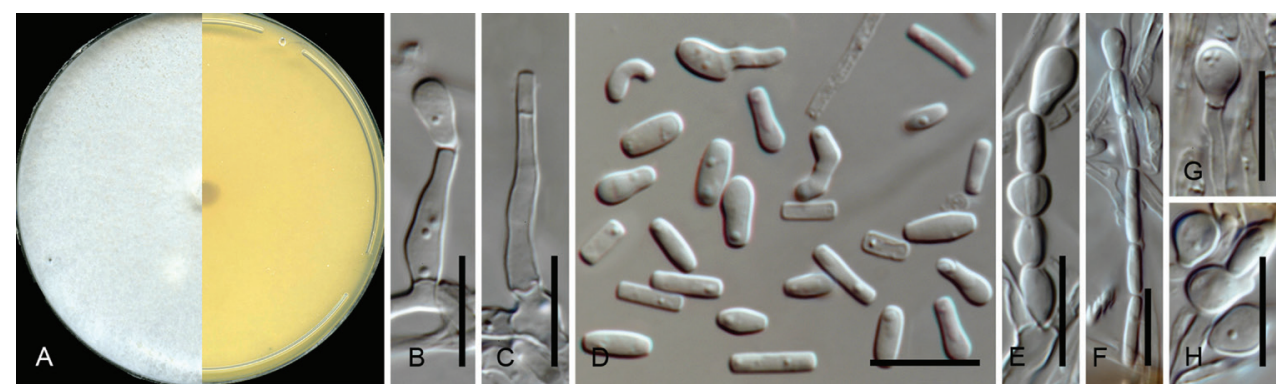

Figure 3. Micrographs of Huntiella krugeri sp. nov. (ex-holotype CMW $36849=$ CBS $131676=$ PPRI 27952). A Culture grown on $2 \%$ MEA in the dark for $34 \mathrm{~d}$ B, C Conidiogenous cell D Conidia in various shapes $\mathbf{E}$ Chain of conidia in different shapes $\mathbf{F}$ Chain of rectangular-shaped conidia with top-end of club-shaped G, H Aleurioconidia. Scale bars: $10 \mu \mathrm{m}(\mathbf{B}-\mathbf{H})$. 
Notes. Huntiella krugeri is closely related to $H$. hellenica described in the present study, $H$. cryptoformis (Mbenoun et al. 2014) and $H$. savannae (Kamgan Nkuekam et al. 2008). Due to its heterothallic nature, $H$. krugeri produced only the asexual state in this study. The bacilliform conidia of $H$. krugeri (average $6.2 \times 1.7 \mu \mathrm{m}$ ) were longer than those of $H$. hellenica (average $5.9 \times 5.3 \mu \mathrm{m}$ ) and $H$. cryptoformis (average $5.5 \times$ $2.5 \mu \mathrm{m}$ ). In addition, $H$. krugeri produced hyaline aleurioconidia, which are absent in other closely-related species in the genus.

\section{Discussion}

This study led to the discovery of two novel Huntiella species isolated from Platanus orientalis in Greece, Colophospermum mopane and Senegalia nigrescens in the Kruger National Park of South Africa. These two species, provided with the name $H$. hellenica and H. krugeri, respectively, were shown to reside in the African Clade of Huntiella (Mbenoun et al. 2014; Liu et al. 2018). The identity of $H$. hellenica and $H$. krugeri emerged from a phylogenetic analysis of DNA sequence data for three gene regions (ITS, BT1 and TEF-1 $\alpha$ ), as well as their distinct morphological characteristics. Mating studies showed that Huntiella hellenica and $H$. krugeri were homothallic and heterothallic, respectively. All indications were that these two species are saprobes that grow on the freshly-exposed surfaces of trees.

The stump of $P$. orientalis, from which $H$. hellenica emerged, was sampled approximately two months after tree felling and it was also infected by the pathogen Ceratocystis platani, which causes a devastating disease in natural stands of P. orientalis in Greece. Colonszation of the stump with $H$. hellenica could have occurred on the freshly-cut surface with a contaminated tool as occurs for $C$. platani (Tsopelas et al. 2017) or was transferred by insect vectors.

The novel species described in this study showed typical characteristics of Huntiella spp. They grew rapidly in culture; their mycelium was white when young and turned dark with age. The one species that displayed a sexual state $-H$. hellenica, produced hat-shaped ascospores and had short conical spines on the ascomatal bases. Temperature is known to influence the ability of Huntiella spp. to produce a sexual state (Wilson et al. 2015) and this was also true for $H$. hellenica, which did not produce acomata below $25^{\circ} \mathrm{C}$.

Comparison of DNA sequence data for multiple gene regions is essential when seeking to identify species in Huntiella (Mbenoun et al. 2014; Liu et al. 2018). The three gene regions, selected for this purpose, have been used in previous studies showing that they can be collectively used to delineate species boundaries in the genus (Van Wyk et al. 2004, 2006, 2011; Kamgan Nkuekam et al. 2012; Mbenoun et al. 2014, 2016; De Errasti et al. 2015; Liu et al. 2018). However, analyses of individual gene regions revealed different levels of resolution, consistent with the results of previous studies on this group of fungi (Mbenoun et al. 2014; Liu et al. 2018). Thus protein coding genes, in this case BT1 and TEF- $1 \alpha$, provided the best resolution for species identification of Huntiella, while ITS sequences provided little information or no support. 
Primers, developed to identify the mating type idiomorphs in Huntiella spp. (Wilson et al. 2015), were effective for this purpose in the present study. The results showed that $H$. hellenica has both mating-type idiomorphs and this explains the presence of sexual structures in all isolates derived from single hyphal tips. In contrast, the isolate of $H$. krugeri contained one mating gene and is clearly a heterothallic species of Huntiella, also consistent with the fact that the isolate produced only an asexual state. This result is also consistent with those of Liu et al. (2018) who showed that closelyrelated Huntiella spp. can have different mating strategies. Collectively, Huntiella spp. have a remarkable range of mating strategies, including homothallic and heterothallic species, as well as those exhibiting unisexuality (Wilson et al. 2015; Liu et al. 2018). The new species described here will contribute to future studies considering the evolution of mating in Huntiella.

The two new species of Huntiella, discovered in this study, bring the total number of species in the genus to 31. These are found in many different regions of the world and on a wide variety of woody substrates (Van Wyk et al. 2004, 2006, 2011; Kamgan Nkuekam et al. 2012; De Beer et al. 2014; Mbenoun et al. 2014, 2016; De Errasti et al. 2015; Liu et al. 2018). The renewed interest that these fungi have received during the course of the past decade has revealed unexpected complexity in their ecological interactions (Mbenoun et al. unpublished data), evolutionary history (Mbenoun et al. 2014; Liu et al. 2018) and reproductive biology (Wilson et al. 2015). The description of novel taxa, as reported in this study and the growing accessibility of whole genome sequencing (Wingfield et al. 2016), should enable new avenues of research that will contribute to a considerably better understanding of Huntiella species in the future.

\section{Acknowledgements}

This study was initiated through the bilateral agreement between the Governments of South Africa and China and supported by The National Key R\&D Program of China (China-South Africa Forestry Joint Research Centre Project; project No. 2018YFE0120900), the National Ten-thousand Talents Program (Project No. W03070115) and the GuangDong Top Young Talents Program (Project No. 20171172). We acknowledge members of Tree Protection and Cooperation Programme (TPCP) and the National Research Foundation (NRF), South Africa for financial support.

\section{References}

Al-Subhi AM, Al-Adawi AO, Van Wyk M, Deadman ML, Wingfield MJ (2006) Ceratocystis omanensis, a new species from diseased mango trees in Oman. Mycological Research 110 : 237-245. https://doi.org/10.1016/j.mycres.2005.08.007 
Chen SF, Van Wyk M, Roux J, Wingfield MJ, Xie YJ, Zhou XD (2013) Taxonomy and pathogenicity of Ceratocystis species on Eucalyptus trees in South China, including C. chinaeucensis sp. nov. Fungal Diversity 58: 267-279. https://doi.org/10.1007/s13225-012-0214-5

Cristobal BD, Hansen AJ (1962) Un hongo semjante a Ceratocystis moniliformis en cacao en Costa Rica. Turrialba 12: 46-47.

Davidson RW (1935) Fungi causing stain in logs and lumber in the southern states, including five new species. Journal of Agricultural Research 50: 789-807.

De Beer ZW, Duong T, Barnes I, Wingfield BD, Wingfield MJ (2014) Redefining Ceratocystis and allied genera. Studies in Mycology 79: 187-219. https://doi.org/10.1016/j.simyco.2014.10.001

De Beer ZW, Marincowitz S, Duong TA, Wingfield MJ (2017) Bretziella, a new genus to accommodate the oak wilt fungus, Ceratocystis fagacearum (Microascales, Ascomycota). MycoKeys 27: 1-19. https://doi.org/10.3897/mycokeys.27.20657

De Errasti A, De Beer ZW, Rajchenberg M, Coetzee MPA, Wingfield MJ, Roux J (2015) Huntiella decorticans sp. nov. (Ceratocystidaceae) associated with dying Nothofagus in Patagonia. Mycologia 107: 512-521. https://doi.org/10.3852/14-175

Grosclaude C, Olivier R, Pizzuto J-C, Romiti C, Madec S (1988) Détection par piégeage $\mathrm{du}$ Ceratocystis fimbriata f. platani. Application à l'étude de la persistance du parasite dans du bois infecté. European Journal of Forest Pathology 18: 385-390. https://doi. org/10.1111/j.1439-0329.1988.tb00226.x

Guindon S, Gascuel O (2003) A simple, fast, and accurate algorithm to estimate large phylogenies by maximum likelihood. Systematic Biology 52: 696-704. https://doi. org/10.1080/10635150390235520

Harrington TC (2004) CABI crop protection compendium. CABI Publishing. http://www. public. iastate.edu/ -tcharrin/cabinfo.html

Heath RN, Wingfield MJ, Wingfield BD, Meke G, Mbaga A, Roux J (2009) Ceratocystis species on Acacia mearnsii and Eucalyptus spp. in eastern and southern Africa including six new species. Fungal Diversity 34: 41-67.

Hedgcock GG (1906) Studies upon some chromogenic fungi which discolor wood. Missouri Botanical Garden Annual Report 17: 59-124. https://doi.org/10.2307/2400089

Kamgan Nkuekam G, Jacobs K, De Beer ZW, Wingfield MJ, Roux J (2008) Ceratocystis and Ophiostoma species including three new taxa, associated with wounds on native South African trees. Fungal Diversity 29: 37-59.

Kamgan Nkuekam G, Wingfield MJ, Mohammed C, Carnegie AJ, Pegg GS, Roux J (2012) Ceratocystis species, including two new species associated with nitidulid beetles, on eucalypts in Australia. Antonie van Leeuwenhoek 101: 217-241. https://doi.org/10.1007/ s10482-011-9625-7

Kamgan Nkuekam G, Wingfield MJ, Roux J (2013) Ceratocystis species, including two new taxa, from Eucalyptus trees in South Africa. Australasian Plant Pathology 42: 283-311. https://doi.org/10.1007/s13313-012-0192-9

Katoh K, Standley DM (2013) MAFFT multiple sequence alignment software version 7: improvements in performance and usability. Molecular Biology and Evolution 30: 772-780. https://doi.org/10.1093/molbev/mst010 
Kearse M, Moir R, Wilson A, Stones-Havas S, Cheung M, Sturrock S, Buxton S, Cooper A, Markowitz S, Duran C, Thierer T, Ashton B, Meintjes P, Drummond A (2012) Geneious Basic: an integrated and extendable desktop software platform for the organization and analysis of sequence data. Bioinformatics 28: 1647-1649. https://doi.org/10.1093/bioinformatics/bts 199

Kile G (1993) Plant diseases caused by species of Ceratocystis sensu stricto and Chalara. Ceratocystis and Ophiostoma: taxonomy, ecology and pathogenicity, 173-183.

Liu FF, Mbenoun M, Barnes I, Roux J, Wingfield MJ, Li GQ, Li JQ, Chen SF (2015) New Ceratocystis species from Eucalyptus and Cunninghamia in South China. Antonie van Leeuwenhoek 107: 1451-1473. https://doi.org/10.1007/s10482-015-0441-3

Liu FF, Li GQ, Roux J, Barnes I, Wilson AM, Wingfield MJ, Chen SF (2018) Nine novel species of Huntiella from southern China with three distinct mating strategies and variable levels of pathogenicity. Mycologia 110: 1145-1171. https://doi.org/10.1080/00275514. 2018.1515450

Mayers CG, McNew DL, Harrington TC, Roeper RA, Fraedrich SW, Biedermann PH, Castrillo LA, Reed SE (2015) Three genera in the Ceratocystidaceae are the respective symbionts of three independent lineages of ambrosia beetles with large, complex mycangia. Fungal Biology 119: 1075-1092. https://doi.org/10.1016/j.funbio.2015.08.002

Mayers CG, Harrington TC, Masuya H, Jordal BH, McNew DL, Shih H-H, Roets F, Kietzka GJ (2020) Patterns of coevolution between ambrosia beetle mycangia and the Ceratocystidaceae, with five new fungal genera and seven new species. Persoonia 44: 41-66. https:// doi.org/10.3767/persoonia.2020.44.02

Mbenoun M, Wingfield MJ, Begoude Boyogueno AD, Wingfield BD, Roux J (2014) Molecular phylogenetic analyses reveal three new Ceratocystis species and provide evidence for geographic differentiation of the genus in Africa. Mycological Progress 13: 219-240. https:// doi.org/10.1007/s11557-013-0907-5

Mbenoun M, Wingfield MJ, Begoude Boyogueno AD, Nsouga AF, Petchayo TS, ten Hoopen GM, Mfegue CV, Dibog L, Nyassé S, Wingfield BD, Roux J (2016) Diversity and pathogenicity of the Ceratocystidaceae associated with cacao agroforests in Cameroon. Plant Pathology 65: 64-78. https://doi.org/10.1111/ppa.12400

Mbenoun M, Garnas JR, Wingfield MJ, Begoude Boyogueno AD, Roux J (2017) Metacommunity analyses of Ceratocystidaceae fungi across heterogeneous African savanna landscapes. Fungal Ecology 28: 76-85. https://doi.org/10.1016/j.funeco.2016.09.007

Moreau C (1952) Coexistence des formes Thielaviopsis et Graphium chez une souche de Ceratocystis major (van Beyma) nov. comb. Remarques sur les variations des Ceratocystis. Revue de Mycologie (Supplément Colonial No. 1) 12: 17-25.

Nel WJ, Duong TA, Wingfield BD, Wingfield MJ, De Beer ZW (2018) A new genus and species for the globally important, multi-host root pathogen Thielaviopsis basicola. Plant Pathology 67: 871-882. https://doi.org/10.1111/ppa.12803

OEPP/EPPO (2014) PM 7/98 (2) Specific requirements for laboratories preparing accreditation for a plant pest diagnostic activity. European and Mediterranean Plant Protection Organization Bulletin - OEPP/EPPO Bullettin 44: 117-147. https://doi.org/10.1111/ epp. 12118 
Posada D (2008) jModelTest: phylogenetic model averaging. Molecular Biology and Evolution 25: 1253-1256. https://doi.org/10.1093/molbev/msn083

Rayner RW (1970) A mycological colour chart. Commonwealth Mycological Institute Kew, Surrey and British Mycological Society.

Ronquist F, Teslenko M, van der Mark P, Ayres DL, Darling A, Höhna S, Larget B, Liu L, Suchard MA, Huelsenbeck JP (2012) MrBayes 3.2: efficient Bayesian phylogenetic inference and model choice across a large model space. Systematic Biology 61: 539-542. https://doi.org/10.1093/sysbio/sys029

Roux J, Wingfield MJ (2009) Ceratocystis species: emerging pathogens of non-native plantation Eucalyptus and Acacia species. Southern Forests: a Journal of Forest Science 71: 115-120. https://doi.org/10.2989/SF.2009.71.2.5.820

Swofford DL (2003) PAUP*. Phylogenetic Analysis Using Parsimony (*and other methods). Version 4. Sunderland, MA, USA: Sinauer Associates.

Tarigan M, Van Wyk M, Roux J, Tjahjono B, Wingfield MJ (2010) Three new Ceratocystis spp. in the Ceratocystis moniliformis complex from wounds on Acacia mangium and A. crassicarpa. Mycoscience 51: 53-67. https://doi.org/10.1007/S10267-009-0003-5

Tsopelas P, Santini A, Wingfield MJ, De Beer ZW (2017) Canker stain: a lethal disease destroying iconic plane trees. Plant Disease 101: 645-658. https://doi.org/10.1094/PDIS-09-161235-FE

Van Wyk M, Roux J, Barnes I, Wingfield BD, Chhetri DB, Kirisits T, Wingfield MJ (2004) Ceratocystis bhutanensis sp. nov., associated with the bark beetle Ips schmutzenhoferi on Picea spinulosa in Bhutan. Studies in Mycology 50: 365-379.

Van Wyk M, Roux J, Barnes I, Wingfield BD, Wingfield MJ (2006) Molecular phylogeny of the Ceratocystis moniliformis complex and description of C. tribilliformis sp. nov. Fungal Diversity 21: 181-201.

Van Wyk M, Wingfield BD, Wingfield MJ (2011) Four new Ceratocystis spp. associated with wounds on Eucalyptus, Schizolobium and Terminalia trees in Ecuador. Fungal Diversity 46: 111-131. https://doi.org/10.1007/s13225-010-0051-3

Van Wyk PWJ, Wingfield MJ, Van Wyk PS (1991) Ascospore development in Ceratocystis moniliformis. Mycological Research 95: 96-103. https://doi.org/10.1016/S09537562(09)81365-8

Von Schrenk H (1903) The "bluing" and the "red-hot" of the western yellow pine, with special reference to the Black Hills Forest Reserve. U.S. Department of Agriculture. Bureau of Plant Industry Bulletin 36: 1-46. https://doi.org/10.5962/bhl.title.65090

Wilson AM, Godlonton T, Van der Nest MA, Wilken PM, Wingfield MJ, Wingfield BD (2015) Unisexual reproduction in Huntiella moniliformis. Fungal Genetics and Biology 80: 1-9. https://doi.org/10.1016/j.fgb.2015.04.008

Wingfield BD, Van Wyk M, Roos H, Wingfield M (2013) Ceratocystis: emerging evidence for discrete generic boundaries. In. The ophiostomatoid fungi: expanding frontiers, 57-64.

Wingfield BD, Duong TA, Hammerbacher A, van der Nest MA, Wilson A, Chang R, de Beer ZW, Steenkamp ET, Wilken PM, Naidoo K, Wingfield MJ (2016) IMA Genome-F 7 Draft genome sequences for Ceratocystis fagacearum, C. harringtonii, Grosmannia penicillata, and Huntiella bhutanensis. IMA Fungus 7: 317-323. https://doi.org/10.5598/imafungus.2016.07.02.11 
Yuan ZQ, Mohammed C (2002) Ceratocystis moniliformopsis sp. nov., an early colonizer of Eucalyptus obliqua logs in Tasmania, Australia. Australian Systematic Botany 15: 125-133. https://doi.org/10.1071/SB00024

\section{Supplementary material I}

Figure S1. ML tree of Huntiella species generated from the ITS DNA sequence data Authors: FeiFei Liu, Seonju Marincowitz, ShuaiFei Chen, Michael Mbenoun, Panaghiotis Tsopelas, Nikoleta Soulioti, Michael J. Wingfield

Data type: phylogenetic tree

Explanation note: Sequences generated from this study are printed in bold type. Bold branches indicate posterior probabilities values $\geq 0.9$. Bootstrap values and posterior probabilities value are presented above branches as $\mathrm{ML} / \mathrm{MP} / \mathrm{BI}$. Bootstrap value $<50 \%$ or probabilities values $<0.9$ are marked with ${ }^{*}$. Nodes lacking the support value are marked with -. Ceratocystis cercfabiensis (CMW 43029) represents the outgroup.

Copyright notice: This dataset is made available under the Open Database License (http://opendatacommons.org/licenses/odbl/1.0/). The Open Database License $(\mathrm{ODbL})$ is a license agreement intended to allow users to freely share, modify, and use this Dataset while maintaining this same freedom for others, provided that the original source and author(s) are credited.

Link: https://doi.org/10.3897/mycokeys.69.53205.suppl1

\section{Supplementary material 2}

Figure S2. ML tree of Huntiella species generated from the BT1 DNA sequence data Authors: FeiFei Liu, Seonju Marincowitz, ShuaiFei Chen, Michael Mbenoun, Panaghiotis Tsopelas, Nikoleta Soulioti, Michael J. Wingfield

Data type: phylogenetic tree

Explanation note: Sequences generated from this study are printed in bold type. Bold branches indicate posterior probabilities values $\geq 0.9$. Bootstrap values and posterior probabilities values are presented above branches as ML/MP/BI. Bootstrap value $<50 \%$ or probabilities values $<0.9$ are marked with *. Nodes lacking the support value are marked with -. Ceratocystis cercfabiensis (CMW 43029) represents the outgroup.

Copyright notice: This dataset is made available under the Open Database License (http://opendatacommons.org/licenses/odbl/1.0/). The Open Database License $(\mathrm{ODbL})$ is a license agreement intended to allow users to freely share, modify, and use this Dataset while maintaining this same freedom for others, provided that the original source and author(s) are credited.

Link: https://doi.org/10.3897/mycokeys.69.53205.suppl2 


\section{Supplementary material 3}

Figure S3. ML tree of Huntiella species generated from the TEF- $1 \alpha$ DNA sequence data

Authors: FeiFei Liu, Seonju Marincowitz, ShuaiFei Chen, Michael Mbenoun, Panaghiotis Tsopelas, Nikoleta Soulioti, Michael J. Wingfield

Data type: phylogenetic tree

Explanation note: Sequences generated from this study are printed in bold type. Bold branches indicate posterior probabilities values $\geq 0.9$. Bootstrap values and posterior probabilities values are presented above branches as ML/MP/BI. Bootstrap value $<50 \%$ or probabilities values $<0.9$ are marked with * Nodes lacking the support value are marked with -. Ceratocystis cercfabiensis (CMW 43029) represents the outgroup.

Copyright notice: This dataset is made available under the Open Database License (http://opendatacommons.org/licenses/odbl/1.0/). The Open Database License $(\mathrm{ODbL})$ is a license agreement intended to allow users to freely share, modify, and use this Dataset while maintaining this same freedom for others, provided that the original source and author(s) are credited.

Link: https://doi.org/10.3897/mycokeys.69.53205.suppl3 